\title{
Pengembangan Video Animasi Pada Muatan Pelajaran Ipa Kelas IV
}

\section{Putu Trisna Angga Semara ${ }^{1 *}$, Anak Agung Gede Agung ${ }^{2}$}

12 Prodi Pendidikan Guru Sekolah Dasar, Universitas Pendidikan Ganesha, Singaraja, Indonesia *e-mail: ipttrisnaanggasemara08@undiksha.ac.id

\begin{abstract}
Abstrak
Rendahnya motivasi siswa untuk belajar disebabkan karena kurangnya media pembelajaran yang membantu siswa dalam belajar. Penelitian ini bertujuan untuk mendeskripsikan proses rancang bangun dari video animasi pada muatan pelajaran IPA dan menganalisis hasil validasi video animasi menurut hasil review para ahli dan uji coba perorangan. Pengembangan video animasi ini menggunakan model penelitian ADDIE yang terdiri dari lima tahap yaitu Analyze, Desain, Development, Implementation, dan Evaluation. Pengumpulan data yang digunakan pada penelitian ini adalah metode kuisioner. Analisis data digunakan metode analisis deskriptif kuantitatif. Hasil analisis data diperoleh yaitu uji ahli isi dengan skor 95 dengan kualifikasi sangat baik, uji ahli desain pembelajaran dengan skor 95 dengan kualifikasi sangat baik, hasil uji ahli media pembelajaran dengan skor 92,5 dengan kualifikasi sangat baik, dan hasil uji coba perorangan dengan skor 95 dengan kualifikasi sangat baik. Berdasarkan hasil analisis data uji produk oleh para ahli disimpulkan bahwa video animasi hasil penelitian ini layak digunakan dalam pembelajaran muatan IPA di kelas IV. Implikasi penelitian ini memberikan media pembelajaran inovatif yang mampu meningkatkan motivasi siswa dalam belajar sehingga berdampak pada hasil belajar siswa yang meningkat.
\end{abstract}

Kata kunci: video animasi , model pengembangan ,IPA

\begin{abstract}
The low motivation of students to learn is caused by a lack of learning media that helps students learn. This study aims to describe the design process of animated videos on science subject content and to analyze the validation results of animated videos according to expert reviews and individual trials. The development of this animated video uses the ADDIE research model which consists of five stages, namely Analyze, Design, Development, Implementation, and Evaluation. Data collection used in this study is a questionnaire method. Data analysis used quantitative descriptive analysis method. The results of data analysis were obtained, namely the content expert test with a score of 95 with very good qualifications, the learning design expert test with a score of 95 with very good qualifications, the results of the learning media expert test with a score of 92.5 with very good qualifications, and the individual trial results with a score 95 with very good qualifications. Based on the results of the analysis of product test data by the experts, it can be concluded that the animated video from the results of this study is suitable for use in learning science content in class IV. The implication of this research is to provide innovative learning media that can increase student motivation in learning so that it has an impact on increased student learning outcomes.
\end{abstract}

Keywords: animation video, development model, science

\footnotetext{
${ }^{*}$ Corresponding author.

Received 30 Januari 2021; Accepted 1 Maret 2021; Available online 8 April 2021 (C) 2021 MI All Rights Reserved
} 


\section{Pendahuluan}

Pendidikan memiliki makna yaitu usaha sadar dan terencana yang berupa bantuan yang diberikan secara sengaja yang berguna untuk mengembangkan segala potensi siswa sebagai tujuan mencapai kedewasaannya (Moma, 2017; Nada, Utaminingsih, \& Ardianti, 2018). Pendidikan mengupayakan sebuah kehidupan kearah yang lebih baik yang akan diperlukan di masa datang (Renny dan Sonbay, 2019). Pendidikan akan mengarahkan seseorang menuju keberhasilan hidup. Faktor yang mempengaruhi keberhasilan pendidikan yaitu motivasi dan minat siswa, kesiapan guru dalam merancang proses pembelajaran serta fasilitas dan media pendukung pembelajaran (Darmadi, 2015; Donas \& Elhefni, 2016). Merancang dan menyiapkan media pembelajaran menjadi tantangan bagi guru. Banyak model serta media pembelajaran inovatif yang dapat digunakan dan diterapkan oleh guru sesuai dengan karakteristik siswa dan materi pembelajaran. Guru dituntut untuk berinovasi dalam memilih media serta model pembelajaran yang tepat sehingga tujuan pembelajaran dapat tercapai secara maksimal. Kemajuan teknologi membuat guru dimudahkan dalam menciptakan suasana belajar yang nyaman dan menyenangkan bagi siswa. Kemajuan teknologi juga memudahkan siswa dalam belajar. Media pembelajaran berbasis IT memudahkan siswa dalam menyerap informasi, sehingga dalam hal ini guru dituntut untuk menggunakan media pembelajaran yang dapat membantu siswa dalam belajar (Maqfiroh, Khutobah, \& Budyawati, 2020; Rosidah, 2016).

Permasalahan yang terjadi saat ini adalah masih banyak guru yang kurang menggunakan media pembelajaran dalam proses pembelajaran (Wulandari, Sudatha, \& Simamora, 2020; Yusnia, 2019). Banyak guru yang mengaku bahwa kesulitan dalam membuat media pembelajaran inovatif yang membantu siswa dalam belajar. Permasalahan ini juga ditemukan pada salah satu sekolah dasar. Berdasarkan hasil wawancara kepada guru wali kelas IV A di SDN 17 Dauh Puri ditemukan bahwa guru kurang menggunakan media pembelajaran dalam proses pembelajaran. Guru hanya menjelaskan materi pembelajaran tanpa bantuan media pembelajaran yang inovatif. Hal ini menyebabkan siswa merasa bosan dan kesulitan dalam memahami materi pembelajaran. Berdasarkan hasil observasi juga didapatkan bahwa kurangnya media pembelajaran yang dapat mendukung materi pembelajaran IPA. Selain itu, konsep materi IPA sangat luas sehingga sulit untuk dipahami siswa. Kurangnya media pembelajaran yang membantu siswa dalam memahami materi pembelajaran berpengaruh pada hasil belajar siswa yang rendah. Siswa juga kurang termotivasi dalam belajar karena proses pembelajaran bersifat monoton sehingga terkadang siswa merasa mengantuk saat proses pembelajaran berlangsung.

Pembelajaran dijenjang sekolah dasar mencakup berbagai muatan mata pelajaran yang dipadukan dalam bentuk Tema didalamnya ada muatan-muatan materi pembelajaran yaitu salah satunya adalah IImu Pengetahuan Alam (IPA). IPA atau science secara harfiah disebut sebagai ilmu yang mempelajarai tentang alam yaitu ilmu yang mempelajari tentang peristiwa-peristiwa yang terjadi di alam (Puspitorini, Subali, \& Jumadi, 2014; Yuliati, 2017). Mempelajari IPA akan mengembangkan rasa ingin tahu, sikap positif dan kesadaran tentang adanya hubungan yang saling mempengaruhi antara IPA, lingkungan, teknologi, dan masyarakat (Anjelina Putri, Swatra, \& Tegeh, 2018; Carlucy, Suadnyana, \& Negara, 2018). Oleh karena itu melalui pembelajaran IPA diharapkan siswa dapat memiliki sikap ilmiah yang ada pada seorang peneliti, yaitu jujur, berani, bertanggung jawab, memiliki rasa ingin tahu, ulet dan gigih, terbuka, mampu membedakan opini dan fakta, dan peduli terhadap lingkungan. Namun, dalam pelaksanaan di dalam kelas guru kurang mampu mengembangkan kemampuan siswa dalam mata pelajaran IPA. Kenyataan tersebut terbukti dari ketika guru mengajar materi IPA selama ini guru hanya menggunakan metode ceramah serta menggunakan media buku tanpa ditunjang media yang konkret hal itu mengakibatkan siswa lebih banyak menghafal teori daripada memahami praktek secara langsung materi IPA itu sendiri .Oleh karena itu, agar tujuan pembelajaran IPA dapat tercapai maka guru harus bisa memilih strategi, model, dan media yang tepat serta menciptakan suasana belajar yang dapat meningkatkan motivasi siswanya untuk belajar. 
Dalam meningkatkan hasil belajar siswa dibutuhkan sebuah inovasi dalam pembelajaran khususnya untuk mata pelajaran IPA. Salah satu inovasi pembelajaran yang bisa digunakan adalah dengan menggunakan media pembelajaran inovatif. Media pembelajaran yang cocok digunakan untuk karakteristik siswa sekolah dasar yaitu menggunakan media video animasi. Video animasi dapat memudahkan siswa dalam memahami materi pembelajaran (Armansyah, Sulton, \& Sulthoni, 2019; Muzakki \& Manan, 2016). Video animasi merupakan penggabungan antara media video dan media animasi. Media animasi yang berbentuk media visual, disempurnakan dengan media video. Video animasi biasanya digunakan untuk mengilustrasikan kejadian yang tidak bisa dilihat secara langsung, misalnya pada materi IPA seperti contoh gerak rotasi bumi, proses fotosintesis pada tumbuhan. Jadi melalui video animasi, proses pembelajaran dan gejala alam tersebut dapat dilihat dengan jelas sehingga mudah bagi siswa untuk memahaminya secara nyata.

Video animasi merupakan sebuah gambar bergerak yang berasal dari kumpulan objek yang disusun secara khusus sehingga bergerak sesuai alur yang sudah ditentukan pada setiap hitungan waktu (Apriansyah, Sambowo, \& Maulana, 2020; Siddiq, Sudarma, \& Simamora, 2020). Objek yang dimaksudkan adalah gambar manusia, tulisan teks, gambar hewan, gambar tumbuhan, gedung, dan lain sebagainya. Video Animasi digunakan untuk menarik perhatian siswa khusunya siswa SD jika digunakan secara tepat, akan tetapi sebaliknya animasi juga dapat mengalihkan perhatian siswa dari isi materi yang disampaikan guru dan mengesampingkan isi dari materi tersebut (Alannasir, 2016; Trianawati, 2019). Oleh karena itu, guru harus bisa mengefektifkan penggunaan animasi dalam pembelajaran, dan mengolah media tersebut agar siswa lebih terfokus pada isi materi daripada animasinya. Penelitian yang dilakukan oleh Awalia, Pamungkas, \& Alamsyah (2019) menyatakan bahwa media animasi dapat meningkatkan minat siswa dalam belajar serta membantu siswa dalam memahami materi pembelajaran. Penelitian yang dilakukan oleh Kasih (2017) menyatakan bahwa penggunaan film animasi efektif ditandai dengan peningkatan hasil belajar yang berarti pada ranah kognitif. Dapat disimpulkan bahwa media pembelajaran berupa animasi dapat meningkatkan minat serta memudahkan siswa dalam belajar sehingga berpengaruh pada hasil belajar siswa yang meningkat.

Pengembangan media pembelajaran dapat dijadikan sebagai cara untuk meningkatkan kualitas pembelajaran di sekolah dasar. Penelitian ini bertujuan untuk mengembangkan video animasi pada mata pelajaran IPA khususnya pada materi siklus hidup atau daur hidup hewan, secara garis besar semua makhluk hidup mengalami siklus hidup atau daur hidup. Diharapkan media video animasi yang dikembangkan dapat memudahkan siswa dalam belajar khususnya mata pelajaran IPA. Selain dapat menarik perhatian siswa, media tersebut diharapkan dapat membuat suasana belajar lebih menyenangkan dan siswa akan termotivasi belajar serta agar siswa memiliki daya tarik didalam proses kegiatan pembelajaran agar pembelajaran dapat lebih bermakna.

\section{Metode}

Penelitian ini merupakan penelitian pengembangan. Metode yang digunakan dalam penelitian pengembangan ini adalah dengan menggunakan model ADDIE yang meliputi Analysis, Design, Development, Implementation dan Evaluation. Analysis berkaitan dengan kegiatan analisis terhadap situasi kerja dan lingkungan sehingga dapat ditemukan produk apa yang perlu dikembangkan. Design merupakan kegiatan perancangan produk sesuai dengan yang dibutuhkan. Development adalah kegiatan pembuatan dan pengujian produk. Implementation adalah kegiatan menggunakan produk, dan Evaluation adalah kegiatan menilai apakah setiap langkah kegiatan dan produk yang telah dibuat sudah sesuai dengan spesifikasi atau belum.

Subjek pada penelitian pengembangan video animasi ini yaitu, 1 orang ahli isi mata pelajaran, 1 orang ahli desain pembelajaran, 1 orang ahli media pembelajaran, 3 orang siswa untuk uji coba perorangan. Metode pengumpulan data pada penelitian pengembangan ini menggunakan metode kuesioner. Metode kuesioner digunakan pada saat analisis 
kebutuhan siswa, uji coba produk pada subjek uji coba yaitu ahli isi muatan pelajaran, ahli desain instruksional, ahli media pembelajaran, uji coba perorangan, dan uji coba kelompok kecil pada siswa. Instrumen pengumpulan data yang digunakan pada penelitian pengembangan ini adalah kuesioner.

Metode analisis data yang digunakan pada penelitian pengembangan ini yaitu metode analisis deskriptif kualitatif dan metode analisis deskriptif kuantitatif. Metode analisis ini digunakan untuk mengolah data dari hasil uji coba ahli materi, ahli desain pembelajaran, ahli media pembelajaran dan uji coba perorangan. Data yang dimaksud berupa kritik, dan saran yang diambil dari kuesioner review ahli isi materi, review ahli desain pembelajaran, review ahli media pembelajaran dan, hasil uji coba perorangan

\section{Hasil dan Pembahasan}

Penyajian data uji coba pengembangan video animasi ini adalah mengenai hasil validitas pengembangan produk video animasi yang dimana hasil validitas pengembangan video animasi ini akan dipaparkan empat pokok bahasan yang meliputi: validitas pengembangan Video menurut (1) ahli isi mata pelajaran, (2) ahli desain pembelajaran, (3) ahli media pembelajaran, (4) uji coba perorangan.Mengingat situasi saat ini yang masih dilanda pandemi Covid -19 sehingga tahap uji coba hanya bisa dilakukan sampai tahap uji coba perorangan.

Kegiatan awal sebelum melakukan pengembangan Video animasi ini adalah melakukan tahap analisis Tahap analisis merupakan suatu proses yang akan mendefinisikan apa yang akan dikembangkan, dan bagaimana ketersediaan dan relevansi buku ajar yang digunakan dalam penelitian ini, analisis yang dilakukan yaitu dengan mengenal karakteristik siswa, analisis konten dan analisis lingkungan sekolah. Analisis karakteristik siswa dilakukan bertujuan untuk mengetahui mengenai karakteristik siswa tentang kapasitas belajaranya, kompetensi pengetahuannya, keterampilan dan sikap yang dimiliki oleh siswa di SDN 17 Dauh Puri Metode yang digunakan untuk mengetahui karakteristik siswa adalah wawancara langsung kepada guru. Pada tahap ini pengembang menganalisis kebutuhan siswa terutama berupa materi dan sumber pembelajaran yang relevan, serta menganalisis media pembelajaran yang akan diterapkan. Pada tahap analisis konten dilakukan pemilihan materi pembelajaran yang tepat dengan menyesesuaikan produk yang nantinya akan dikembangkan disertai analisis karakteristik dan kemampuan yang dimiliki masing-masing siswa. Berdasarkan hasil analisis konten yang diperoleh, maka materi yang akan dicantumkan dalam video animasi ini adalah mengenai siklus hidup pada mata pelajaran IPA. Pada tahap analisis konten ini, selain menentukan materi yang akan digunakan pada video animasi juga dilakukan identifikasi kompetensi inti dan kompetensi dasar pada mata pelajaran IPA. Pada tahap analisis lingkungan dan fasilitas menunjukkan bahwa sekolah sudah memiliki fasilitias yang memadai seperti sudah adanya projektor serta LCD yang digunakan untuk menunjang proses belajar mengajar di SDN 17 Dauh Puri, sehingga video animasi cocok dikembangkan.

Tahap selanjutnya adalah desain. Pada tahap ini yang dilakukan dalam pengembangan video animasi adalah melakukan perancangan. Pada tahap ini kegiatan yang dilakukan adalah membuat rancangan desain (storyboard) dan mendesain komponen media dengan menggunakan softweare Adobe Premiere Pro. Pada tahap pengembangan (Development) dilakukan perancangan bahan-bahan video animasi seperti kesesuaian materi yang akan digunakan untuk mengajar, aplikasi yang digunakan untuk mengedit dan perancangan video animasi. Selanjutnya merancang video animasi untuk mata pelajaran IPA dengan berbantuan aplikasi Adobe Premiere Pro. Pada tahap Implementasi (Implementation) kegiatan yang dilakukan adalah penerapan video animasi yang telah dikembangkan untuk mendapatkan respon siswa dari segi kemenarikan dan kelayakan video animasi. Pada tahap terakhir evaluasi merupakan proses untuk melihat apakah pengembangan media video animasi yang telah dirancang telah berhasil atau sesuai dengan harapan yang sudah direncanakan. Evaluasi dapat dilakukan melalui tahapan yaitu dengan 
cara formatif. Evaluasi formatif dilakukan untuk mengukur atau menilai produk media pembelajaran yang mencakup validasi para ahli yaitu ahli isi mata pelajaran, ahli desain pembelajaran, dan ahli media pembelajaran serta dilakukan uji coba perorangan .

Pada hasil validasi video animasi ini akan dipaparkan empat pokok bahasan, yaitu: (1) uji ahli mata pelajaran, (2) uji ahli desain pembelajaran, (3) uji ahli media pebelajaran, (4) uji coba peroranganKeempat data tersebut akan disajikan secara berurutan sesuai dengan hasil yang diperoleh dari masing-masing tahapan uji coba. Hasil validitas pengembangan video animasi menurut uji ahli mata pelajaran, uji ahli desain pembelajaran, dan uji ahli media pembelajaran, uji coba perorangan, uji coba kelompok kecil, secara lebih terprinci dapat dilihat pada tabel 1 .

Tabel 1. Persentase Hasil Validitas Pengembangan video animasi

\begin{tabular}{|c|c|c|}
\hline Subjek uji coba & Hasil Validitas(\%) & Keterangan \\
\hline 1 Uji Ahli Isi Mata pelajaran & 95 & Sangat Baik \\
\hline 2 Uji ahli DesaiPembelajaran & 95 & Sangat Baik \\
\hline 3 Uji Ahli Media Pembelajaran & 92,5 & Sangat Baik \\
\hline 4 Uji Coba Perorangan & 95 & Sangat Baik \\
\hline
\end{tabular}

Berdasarkan tabel 1 menunjukkan bahwa persentase hasil validitas pengembangan video animasi menurut subjek uji coba secara berturut-turut sebesar 95\%, 95\%, 92,5\%, 95\%. Sesuai perolehan hasil dari uji ahli isi mata pelajaran IPA, selanjutnya hasil tersebut dikonversikan dengan tabel konversi tingkat pencapaian skala 4. Maka persentase tingkat pencapaian hasil ahli isi mata pelajaran IPA adalah 95\% dan berada pada kualifikasi sangat baik. Berdasarkan analisis terhadap masukan, komentar dan saran ahli isi ada saran yang sifatnya revisi pada RPP dan soal yang akan diberikan pada siswa. Beberapa saran tersebut kemudian dijadikan sebagai bahan rujukan untuk perbaikan video animasi agar bisa lebih baik lagi. Adapun masukan serta saran dan komentar yang diberikan oleh ahli isi materi untuk video animasi ini, dapat disajikan pada Tabel 2.

Tabel 2. Revisi Produk Ahli Isi Materi

\begin{tabular}{|c|c|c|}
\hline No & Komentar dan Saran & Revisi \\
\hline 1 & $\begin{array}{l}\text { Dalam RPP harus dicantumkan } \\
\text { materi yang sesuai dengan video } \\
\text { yang ditampilkan }\end{array}$ & $\begin{array}{l}\text { Mencantumkan materi yang digunakan dalam } \\
\text { video pada RPP }\end{array}$ \\
\hline 2 & Soal harus berisikan kunci jawaban & Menambahkan kunci jawaban pada soal \\
\hline
\end{tabular}

Sesuai perolehan hasil dari uji ahli desain pembelajaran, selanjutnya hasil tersebut dikonversikan dengan tabel konversi tingkat pencapaian skala 4. Maka persentase tingkat pencapaian hasil ahli desain pembelajaran adalah 95\% dan berada pada kualifikasi sangat baik. Berdasarkan analisis terhadap masukan, komentar dan saran ahli isi ada saran yang sifatnya revisi dengan menambahkan panduan atau pedoman penggunaan video animasi. Adapun masukan serta saran dan komentar yang diberikan oleh ahli desain pembelajaran untuk video animasi ini, dapat disajikan pada Tabel 3.

Tabel 3. Revisi Produk Ahli Isi Materi

\begin{tabular}{|c|c|c|c|}
\hline No & Komentar dan Saran & Revisi & \\
\hline 1 & $\begin{array}{l}\text { Buat panduan atau pedoman } \\
\text { di dalam pengqunaan media }\end{array}$ & $\begin{array}{l}\text { Membuat pedoman mengenai } \\
\text { mengoperasikan video animasi }\end{array}$ & cara \\
\hline
\end{tabular}


Sesuai perolehan hasil dari uji ahli media pembelajaran, selanjutnya hasil tersebut dikonversikan dengan tabel konversi tingkat pencapaian skala 4. Maka persentase tingkat pencapaian hasil ahli media pembelajaran adalah $92,5 \%$ dan berada pada kualifikasi sangat baik. Berdasarkan analisis terhadap masukan, komentar dan saran ahli isi ada saran yang sifatnya revisi dengan membuat cover cd video animasi dan menambahkan identitas mahasiswa serta dosen pembimbing dalam video animasi. Adapun masukan serta saran dan komentar yang diberikan oleh ahli media pembelajaran untuk video animasi ini, dapat disajikan pada Tabel 4.

Tabel 4. Revisi Produk Ahli Media Pembelajaran

\begin{tabular}{cll}
\hline No & \multicolumn{1}{c}{ Komentar dan Saran } & \multicolumn{1}{c}{ Revisi } \\
\hline 1 & Buat cover CD video animasi & Membuat cover CD untuk video animasi \\
2 & $\begin{array}{l}\text { Tambah identitas mahasiswa dan } \\
\text { dosen pembimbing dalam video }\end{array}$ & $\begin{array}{l}\text { Menambahkan } \\
\text { mahasiswa,sertadosen pembimbing langsung } \\
\text { pada video animasi }\end{array}$ \\
\hline
\end{tabular}

Perolehan hasil dari uji coba perorangan, selanjutnya hasil tersebut dikonversikan dengan tabel konversi tingkat pencapaian skala 4. Maka persentase tingkat pencapaian hasil uji coba perorangan adalah $95 \%$ berada pada kualifikasi sangat baik. Berdasarkan analisis terhadap masukan, komentar dan saran siswa, tidak ada saran yang sifatnya revisi. Revisi tidak dilakukan mengingat perolehan kualifikasi dari video animasi sangat baik, sehingga dapat dijadikan pertimbangan untuk tidak dilakukannya revisi. Berdasarkan perolehan dari pada ahli dan hasil uji coba maka dapat disimpulkan bahwa media pembelajaran video animasi yang dikembangkan layak digunakan dalam proses pembelajaran, hal ini disebabkan oleh beberapa faktor yaitu sebagai berikut.

Pertama, media video animasi yang dikembangkan mendapatkan kualifikasi sangat baik disebabkan media ini memudahkan siswa dalam memahami materi pembelajaran pada mata pelajaran IPA. Dinilai dari aspek kesesuaian tujuan, indikator dan kompetensi dasar siswa dengan materi yang disampaikan sudah sesuai dengan tujuan pembelajaran dan kurikulum yang digunakan di SDN 17 Dauh Puri adalah Kurikulum 2013. Dalam membyat edia harus memperhatikan kesesuaian antara isi materi dengan tujuan pembelajaran yang dituntut tercapai oleh peserta didik, karena elemen tersebut saling berkaitan satu sama lain untuk dapat menciptakan bahan ajar yang baik (Mustofa \& Syafi'ah, 2018; Tegeh, Simamora, \& Dwipayana, 2019). Penelitian yang dilakukan oleh Fadillah \& Jamilah (2016) mengungkapkan bahwa media pembelajaran harus memiliki fokus yang jelas pada tujuan pembelajaran, indikator dan kompetensi dasar siswa. Dalam pengembangan suatu media pembelajaran, kesesuaian materi yang diulas nantinya pada media pembelajaran tersebut harus sesuai dengan tujuan pembelajaran yang telah ditetapkan (Tegeh et al., 2019; Widjiningsih, Sugiyono, \& Gafur, 2014). Kejelasan dan keterkaiatan antara media pembelajaran dengan indikator, tujuan, dan materi, harus menjadi perhatian dan pertimbangan pengajar untuk memilih dan menggunakan media dalam proses pembelajaran di kelas sehingga media yang digunakan lebih efektif dan efisien untuk mencapai tujuan pembelajaran. Dapat disimpulkan bahwa kejelasan dan keterkaitan antara indikator pembelajaran, kompetensi dasar, tujuan pembelajaran, materi, serta kesesuaian evaluasi dengan tujuan pembelajaran yang terkandung didalam media pembelajaran akan mampu memudahkan siswa dalam memahami materi pembelajaran sehingga tujuan pembelajaran akan tercapai dengan maksimal.

Kedua, media video animasi yang dikembangkan mendapatkan kualifikasi sangat baik disebabkan karena dapat menarik perhatian siswa dalam belajar. Desain pembelajaran memegang peranan yang sangat penting untuk meningkatan kualitas pembelajaran (Gafur, 2012; Setiawan, 2020). Video animasi yang dikembangkan didesain sedemikian rupa agar tercipta tulisan, gambar dan karakter berwarna, audio (suara), dan animasi dalam satu kesatuan sehingga mampu memberikan daya tarik tersendiri kepada siswa untuk belajar 
lewat sajian materi audio visual. Materi pembelajaran berupa teks atau abstrak akan lebih sulit untuk dipahami oleh siswa, jika divisualisasikan dengan gambar akan mampu memudahkan dalam mengingat pesan dan dapat meningkatkan motivasi siswa (Rosnihayati, 2017; Sudarma, Tegeh, \& Prabawa, 2015). Teori dari Sudarma, dkk (2015) tentang kesesuaian penggunaan warna akan mempengaruhi minat siswa, warna yang baik digunakan untuk perpaduan background dengan tulisan adalah jika warna background gelap maka tulisan berwarna terang.

Ketiga, media video animasi yang dikembangkan mendapatkan kualifikasi sangat baik disebabkan karena dapat meningkatkan motivasi siswa dalam belajar. Susiana \& Wening, (2015) mengemukakan motivasi dan perhatian siswa dapat ditingkatkan melalui multimedia, pembelajaran lebih menarik bagi siswa, meningkatkan hasil pembelajaran dan mempersingkat waktu penyajian pembelajaran. Hal itu dikarenakan video animasi ini sangat mudah diakses dimanapun. Hal ini sejalan dengan penelitian yang dilakukan oleh Irawan (2018) menyatakan bahwa kemudahan mengakses atau menggunakan media akan dapat membuat siswa lebih sering membuka kembali materi yang disampaikan diluar jam pelajaran. Video animasi dapat menarik minat, perhatian, dan motivasi siswa selama pembelajaran berlangsung, karena dengan video animasi siswa dapat mempelajari keadaan secara nyata dari suatu proses yang rumit atau fenomena tertentu. Penelitian yang dilakukan oleh Siddiq et al., (2020) juga menyatakan bahwa video animasi dapat meningkatkan motivasi siswa dalam belajar. Penelitian yang dilakukan oleh Rosmiati (2019) juga menyatakan bahwa animasi interaktif dapat meningkatkan motivasi siswa dalam belajar sehingga berpengaruh pada hasil belajar siswa.

Dengan adanya video animasi dalam menunjang proses pemebelajaran. Implikasi penelitian ini yaitu siswa dapat melakukan tayangan ulang pada fenomena tertentu untuk melihat gambaran yang lebih fokus dan nyata, sesuai dengan prinsip belajar IPA. Melalui video animasi ini siswa lebih dimudahkan dalam pembelajaran. Video animasi yang dibuat, siswa diharapkan dapat memiliki sikap ilmiah yaitu berpikir kritis, memiliki rasa ingin tahu, ulet dan gigih, terbuka, mampu membedakan opini dan fakta, dan peduli terhadap lingkungan.

\section{Simpulan}

Berdasarkan hasil penilaian yang dilakukan oleh ahli isi mata pelajaran, desain pembelajaran, ahli media pembelajaran, serta hasil uji coba perorangan diperoleh hasil bahwa media yang dikembangkan mendapatkan kualifikasi sangat baik. Dapat disimpulkan bahwa media video animasi yang dikembangkan layak diterapkan untuk memudahkan siswa dalam memahami materi pembelajaran IPA.

\section{Daftar Pustaka}

Alannasir, W. (2016). Pengaruh Penggunaan Media Animasi Dalam Pembelajaran IPS Terhadap Motivasi Belajar Siswa Kelas IV SD Negeri Mannuruki. Journal of Educational Science and Technology, 2(2), 81-90. https://doi.org/https://doi.org/10.26858/est.v2i2.2561.

Anjelina Putri, A. A., Swatra, I. W., \& Tegeh, I. M. (2018). Pengaruh Model Pembelajaran Pbl Berbantuan Media Gambar Terhadap Hasil Belajar Ipa Siswa Kelas lii Sd. Mimbar IImu, 23(1). https://doi.org/10.23887/mi.v23i1.16407

Apriansyah, Sambowo, \& Maulana. (2020). Pengembangan Media Pembelajaran Video Berbasis Animasi Mata Kuliah IImu Bahan Bangunan Di Program Studi Pendidikan Teknik Bangunan Fakultas Teknik Universitas Negeri Jakarta. Jurnal Pendidikan Teknik Sipil (Jpensil), 9(1), 8-18. Retrieved from http://journal.unj.ac.id/unj/index.php/jpensil

Armansyah, F., Sulton, S., \& Sulthoni, S. (2019). Multimedia Interaktif Sebagai Media 
Visualisasi Dasar-Dasar Animasi. Jurnal Kajian Teknologi Pendidikan, 2(3), 224-229. https://doi.org/10.17977/um038v2i32019p224

Awalia, I., Pamungkas, A. S., \& Alamsyah, T. P. (2019). Pengembangan Media Pembelajaran Animasi Powtoon pada Mata Pelajaran Matematika di Kelas IV SD. Jurnal Matematika Kreatif-Inovatif, 10(1). https://doi.org/https://doi.org/10.15294/kreano.v10i1.18534

Carlucy, Suadnyana, \& Negara. (2018). Pengaruh Model Pembelajaran Inkuiri Terbimbing Berbantuan Media Konkret Terhadap Kompetensi Pengetahuan IPA. Mimbar IImu Undiksha, 23(2), 162-169. https://doi.org/https://doi.org/10.23887/mi.v23i2.16416

Darmadi, H. (2015). Tugas, Peran,Kompetensi, dan Tanggung Jawab Menjadi Guru Profesional. Jurnal Edukasi, https://doi.org/http://dx.doi.org/10.31571/edukasi.v13i2.113

Donas, \& Elhefni. (2016). Pengaruh Penerapan Pembelajaran Bermakna (Meaningfull Learning) Pada Pembelajaran Tematik IPS Terpadu Terhadap Hasil Belajar Siswa Kelas III di MI Ahliyah IV Palembang. JIP: Jurnal IImiah PGMI, 2(1), 19-28. Retrieved from http://jurnal.radenfatah.ac.id/index.php/jip/article/view/1063

Fadillah, \& Jamilah. (2016). Pengembangan Bahan Ajar Struktur Aljabar Untuk Meningkatkan Kemampuan Pembuktian Matematis Mahasiswa. Cakrawala Pendidikan, 35(1), 106-108. https://doi.org/https://doi.org/10.21831/cp.v1i1.8379

Gafur, A. (2012). Desain Pembelajaran Konsep, Model, dan Aplikasinya dalam Perencanaan Pelaksanaan Pembelajaran. Yogyakarta: Penerbit Ombak.

Irawan, H. (2018). Keefektifan E-Learning Sebagai Media Pembelajaran (Studi Evaluasi Model Pembelajaran E-Learning Smk Telkom Sandhy Putra Purwokerto). Jurnal Inovasi Teknologi Pendidikan, 5(1), 1-11. https://doi.org/https://doi.org/10.21831/jpv.v3i1.1584

Kasih, F. R. (2017). Pengembangan Film Animasi dalam Pembelajaran Fisika pada Materi Kesetimbangan Benda Tegar di SMA. Tadris: Jurnal Keguruan Dan IImu Tarbiyah, 2(1). https://doi.org/https://doi.org/10.24042/tadris.v2i1.1737

Maqfiroh, Khutobah, \& Budyawati. (2020). Pengembangan Media MOTIF (Monopoli Edukatif) dalam Pembelajaran berbasis Multiple intelligence. Cakrawala Dini: Jurnal Pendidikan Anak Usia Dini, 11(1), 64-74. Retrieved from https://ejournal.upi.edu/index.php/cakrawaladini/article/view/24230/12062

Moma. (2017). Pengembangan Kemampuan Berpikir Kreatif dan Pemecahan Masalah Matematis Mahasiswa Melalui Metode Diskusi. Cakrawala Pendidikan, 36(1), 130 139. Retrieved from https://journal.uny.ac.id/index.php/cp/article/view/10402/pdf

Mustofa, R., \& Syafi'ah, R. (2018). Pengembangan Media Pembelajaran Pop Up Book Materi Kenampakan Permukaan Bumi Mata Pelajaran IPA Kelas III SD. ELSE (Elementary School Education Journal), 2, 30-41. https://doi.org/http://dx.doi.org/10.30651/else.v2i2.1723

Muzakki, \& Manan. (2016). Pengembangan Media Animasi Pembelajaran Interaktif Pokok Bahasan Gaya pada Mata Pelajaran IPA Kelas IV SD. Edcomtech Jurnal Kajian Teknologi Pendidikan, 1(2), 147-152. Retrieved from http://journal2.um.ac.id/index.php/edcomtech/article/view/1802

Nada, I., Utaminingsih, S., \& Ardianti, S. D. (2018). Penerapan Model Open Ended Problems Berbantuan Cd Pembelajaran Untuk Meningkatkan Kemampuan Berpikir Kreatif Siswa Kelas Iv Sd 1 Golantepus. Jurnal Pendidikan Sekolah Dasar, 4(2), 216. https://doi.org/10.30870/jpsd.v4i2.3856

Puspitorini, Subali, \& Jumadi. (2014). Penggunaan Media Komik Dalam Pembelajaran IPA 
Untuk Meningkatkan Motivasi Dan Hasil Belajar Kognitif Dan Afektif. Cakrawala Pendidikan, 33(3), $\quad 413-420 . \quad$ Retrieved from https://journal.uny.ac.id/index.php/cp/article/view/2385/pdf

Renny, Sonbay, Yohana, R. (2019). the Effect of Open-Ended Teaching Model on Mathematics. Jurnal Kependidikan Matematika, 1(2), 105-110. Retrieved from https://journal.unwira.ac.id/index.php/ASIMTOT

Rosidah, A. (2016). Penerapan Media Pembelajaran Visual Untuk Meningkatkan Pemahaman Konsep Siswa Pada Mata Pelajaran IPS. Jurnal Cakrawala Pendas, 2(2). https://doi.org/10.31949/jcp.v2i2.499

Rosmiati, M. (2019). Animasi Interaktif Sebagai Media Pembelajaran Bahasa Inggris Menggunakan Metode ADDIE. Paradigma: Jurnal Komputer Dan Informatika Univiersitas Bina Sarana Informatika, 21(2). https://doi.org/https://doi.org/10.31294/p.v21i2.6019

Rosnihayati. (2017). Penggunaan Media Gambar untuk Meningkatkan Hasil Belajar IPS Siswa Kelas II SDN 003 Pagaran Tapah Darussalam Kabupaten Rokan Hulu. Primary: Jurnal Pendidikan Guru Sekolah Dasar, 6(1), 306-313. Retrieved from https://primary.ejournal.unri.ac.id/index.php/JPFKIP/article/view/4110/3984

Setiawan, A. R. (2020). Desain Pembelajaran Tematik untuk Membimbing Siswa Sekolah Dasar dalam Memperoleh Literasi Saintifik. Journal of Petrology, 369(1), 1689-1699. https://doi.org/10.1017/CBO9781107415324.004

Siddiq, Sudarma, \& Simamora. (2020). Pengembangan Animasi Dua Dimensi Pada Pembelajaran Tematik Untuk Siswa Kelas III Sekolah Dasar. Jurnal Edutech Undiksha, 8(2), 49-63. https://doi.org/http://dx.doi.org/10.23887/jeu.v8i2.28928

Sudarma, I. ., Tegeh, \& Prabawa. (2015). Desain Pesan Kajian Analisis Desain Visual Teks dan Image. Yogyakarta: Graha IImu.

Susiana, R., \& Wening, S. (2015). Pengaruh Model Direct Instruction Berbantuan Multimedia Terhadap Motivasi Belajar Dan Pencapaian Kompetensi Pembuatan Desain Busana. Jurnal Vokasi Pendidikan, 5(3). https://doi.org/https://doi.org/10.21831/jpv.v5i3.6491

Tegeh, Simamora, \& Dwipayana. (2019). Pengembangan Media Video Pembelajaran Dengan Model Pengembangan 4D Pada Mata Pelajaran Agama Hindu. Jurnal Mimbar IImu, 24(2), 158-166. https://doi.org/http://dx.doi.org/10.23887/mi.v24i2.21262

Trianawati. (2019). Pengaruh Model Discovery Learning Berbantuan Media Animasi Terhadap Kompetensi Pengetahuan IPA Siswa Kelas IV SDN Gugus VI Abiansemal Tahun Ajaran 2018/2019. International Journal of Elementary Education, 4. https://doi.org/http://dx.doi.org/10.23887/ijee.v4i1.24337

Widjiningsih, Sugiyono, \& Gafur. (2014). Efektivitas Dan Efisiensi Pembelajaran Teknik Draping Berbantuan Video Di Perguruan Tinggi. Cakrawala Pendidikan, 1(33), 62-70. Retrieved from https://journal.uny.ac.id/index.php/cp/article/view/1862/pdf33

Wulandari, Sudatha, \& Simamora. (2020). Pengembangan Pembelajaran Blended Pada Mata Kuliah Ahara Yoga Semester II di IHDN Denpasar. Jurnal Edutech Undiksha, 8(1), 1-15. https://doi.org/http://dx.doi.org/10.23887/jeu.v8i1.26459

Yuliati, Y. (2017). Literasi sains dalam pembelajaran IPA. Jurnal Cakrawala Pendas, 3(2). https://doi.org/http://dx.doi.org/10.31949/jcp.v3i2.592

Yusnia, Y. (2019). Penggunaan Media Video Scribe Dalam Pembelajaran Literasi Sains Untuk Mahasiswa PGPAUD. Cakrawala Dini: Jurnal Pendidikan Anak Usia Dini, 10(1), 71-75. 